\title{
Intravenous immunoglobulin therapy for severe Clostridium difficile colitis
}

\author{
J Salcedo, S Keates, C Pothoulakis, M Warny, I Castagliuolo, J T LaMont, C P Kelly
}

Section of

Gastroenterology,

Boston University

School of Medicine,

Boston,

Massachusetts, USA

J Salcedo

Gastroenterology

Division, Beth Israel

Deaconess Medical

Center, Harvard

Medical School,

Boston,

Massachusetts, USA

M Warny

$S$ Keates

C Pothoulakis

I Castagliuolo

J T LaMont

C P Kelly

Correspondence to:

Dr C P Kelly, Dana 601,

Gastroenterology, Beth Israe

Deaconess Medical Center,

330 Brookline Avenue,

Boston, MA 02215, USA.

Accepted for publication 2 May 1997

\begin{abstract}
Background-Many individuals have serum antibodies against Clostridium difficile toxins. Those with an impaired antitoxin response may be susceptible to recurrent, prolonged, or severe $\boldsymbol{C}$ difficile diarrhoea and colitis.

Aims-To examine whether treatment with intravenous immunoglobulin might be effective in patients with severe pseudomembranous colitis unresponsive to standard antimicrobial therapy.

Patients-Two patients with pseudomembranous colitis not responding to metronidazole and vancomycin were given normal pooled human immunoglobulin intravenously (200-300 $\mathrm{mg} / \mathrm{kg}$ ).

Methods-Antibodies against $C$ difficile toxins were measured in nine immunoglobulin preparations by ELISA and by cytotoxin neutralisation assay.

Results-Both patients responded quickly as shown by resolution of diarrhoea, abdominal tenderness, and distension. All immunoglobulin preparations tested contained IgG against $C$ difficile toxins $A$ and $B$ by ELISA and neutralised the cytotoxic activity of $C$ difficile toxins in vitro at IgG concentrations of $0.4-1.6 \mathrm{mg} / \mathrm{ml}$.

Conclusion-Passive immunotherapy with intravenous immunoglobulin may be a useful addition to antibiotic therapy for severe, refractory $C$ difficile colitis. IgG antitoxin is present in standard immunoglobulin preparations and $C$ difficile toxin neutralising activity is evident at IgG concentrations which are readily achieved in the serum by intravenous immunoglobulin administration. (Gut 1997; 41: 366-370)
\end{abstract}

Keywords: Clostridium difficile; toxin; diarrhoea; IgG; immunotherapy; antibiotic

Clostridium difficile antibiotic associated colitis is an important cause of morbidity in hospital and nursing home patients. ${ }^{1}$ As many as $26 \%$ of hospital patients are colonised by $C$ difficile and up to one third of these develop diarrhoea. ${ }^{2}$ There is a wide spectrum of host response to $C$ difficile infection ranging from asymptomatic carriage to fulminant colitis with toxic megacolon. ${ }^{1} C$ difficile colitis is mediated by two large protein exotoxins released by pathogenic strains of the bacterium. ${ }^{13-7}$ Toxin $\mathrm{A}$ is a $308 \mathrm{kDa}$ protein which is both a cytotoxin and a potent inflammatory enterotoxin. ${ }^{8-10}$ Toxin $\mathrm{B}$, a $280 \mathrm{kDa}$ protein, is a more potent cytotoxin than toxin A but is not enterotoxic for rodent intestine. $^{711}$ However, toxin $\mathrm{B}$ may be even more harmful to human colon than toxin A. ${ }^{6}$ Both toxins share the same intracellular mechanism of cytotoxicity. They act as enzymes to glucosylate a threonine residue on small GTP binding rho proteins. ${ }^{12}{ }^{13}$ This leads to the disaggregation of actin filaments, collapse of the cytoskeleton, and cell rounding.

The presence or absence of an adequate antibody response to $C$ difficile toxins may play an important role in determining the severity of diarrhoea and colitis. ${ }^{14}$ Serum antibodies to toxins $\mathrm{A}$ and $\mathrm{B}$ are evident in two thirds of healthy adults. ${ }^{15-17}$ Patients with low antitoxin antibody levels are reported to have more severe, more prolonged, or recurrent $C$ difficile diarrhoea whereas asymptomatic carriers have higher antitoxin levels. ${ }^{18-23}$ We previously reported that children with recurrent $C$ difficile diarrhoea had low levels of serum IgG against $C$ difficile toxin $\mathrm{A} .{ }^{21}$ When these children were treated with intravenous immunoglobulin their serum antitoxin levels increased and their diarrhoea resolved. We now report the use of intravenous immunoglobulin therapy in two adults with severe pseudomembranous colitis which failed to respond to standard antibiotic treatment with metronidazole and vancomycin. We also demonstrate that normal human pooled immunoglobulin contains antibodies against $C$ difficile toxins $\mathrm{A}$ and $\mathrm{B}$ which can neutralise the cytotoxic effects of these toxins.

\section{Methods}

MEASUREMENT OF ANTI-C DIFFICILE IgG IN IMMUNOGLOBULIN PREPARATIONS

Nine human immunoglobulin preparations intended for intravenous administration were studied. Three batches of immunoglobulin were obtained from each of the following producers: Alpha Therapeutic Corporation (Los Angeles, California, USA), Armour Pharmaceutical Company (Kankakee, Illinois, USA), and Baxter Healthcare Corporation (Glendale, California, USA). All were highly purified preparations of intact unmodified IgG isolated from large pools of human plasma by cold alcohol fractionation.

Human IgG levels to $C$ difficile antigens were measured by enzyme linked immunosorbent assay (ELISA) as previously described..$^{152124}$ IgG directed against highly purified $C$ difficile toxins $\mathrm{A}$ and $\mathrm{B}$ and against a culture filtrate of toxigenic $C$ difficile (strain VPI 10463) were measured separately. The $C$ difficile culture filtrate contains toxins $\mathrm{A}$ and $\mathrm{B}$ as well as non-toxin $C$ difficile antigens. ELISA results are 
expressed as optical density readings at $450 \mathrm{~nm}^{15}{ }^{2124}$

MEASUREMENT OF C DIFFICILE TOXIN

NEUTRALISING ACTIVITY IN IMMUNOGLOBULIN

PREPARATIONS

Cytotoxicity was determined by rounding of fibroblasts (R9AB, American Type Culture Collection, Rockville, Maryland, USA) in monolayer culture after exposure to $C$ difficile toxins. ${ }^{5425}$ The minimum $50 \%$ cytotoxic dose for each toxin preparation, defined as the minimum dose resulting in $50 \%$ cell rounding at 24 hours, was $0.1 \mathrm{ng} / \mathrm{ml}$ for toxin $\mathrm{A}, 0.003 \mathrm{ng} / \mathrm{ml}$ for toxin $B$, and $0.5 \mathrm{ng} / \mathrm{ml}$ for culture filtrate in these experiments. Inhibition of cytotoxicity was quantified by adding serial twofold dilutions of the immunoglobulin preparations to four times the minimum $50 \%$ cytotoxic dose of each toxin preparation. After 20 minutes the toxin/immunoglobulin mixture was added to fibroblast monolayer cultures and cell rounding was assessed after 24 hours. Controls included human serum albumin diluted to the same protein concentration as the IgG and serum from a healthy volunteer who lacked specific antibodies against $C$ difficile toxin $\mathrm{A}$ or toxin $\mathrm{B}$ as determined by ELISA. ${ }^{15}{ }^{23}$ Results are expressed as the lowest concentration of human IgG required to prevent rounding of $50 \%$ of the fibroblasts. ${ }^{24}$

\section{Case reports and Results}

PATIENT 1

A 63 year old woman developed diarrhoea, cramping abdominal pain, and abdominal distension five days after laparotomy for staging of non-Hodgkin's lymphoma. She received intravenous ceftazidime perioperatively but had not been treated with cytotoxic chemotherapy. She had a peripheral blood leucocytosis of 22000 cells $/ \mu \mathrm{l}$ with $6 \%$ band forms. Flexible sigmoidoscopy and biopsy demonstrated pseudomembranous colitis of the rectum and sigmoid colon. Treatment was begun with both intravenous metronidazole $(500 \mathrm{mg}$, six hourly) and oral vancomycin (250 mg, six hourly). After five days she continued to suffer from profuse diarrhoea and had a persistent leucocytosis of 21000 cells $/ \mu$ l. The patient's abdomen became distended and diffusely tender. A plain abdominal radiograph showed an ileus pattern with both small intestinal and colonic dilatation. A computed tomogram showed dilatation of the colon and the presence of ascites (fig 1). Intravenous immunoglobulin was administered $(300 \mathrm{mg} / \mathrm{kg})$. The diarrhoea improved rapidly. After 36 hours her abdominal pain and distension had resolved and her white blood cell count was normal at 9800 cells $/ \mu \mathrm{l}$. Treatment with metronidazole and vancomycin was continued for a further 10 days. One month later she suffered a recurrence of diarrhoea and had a positive stool cytotoxin assay. On this occasion she responded to treatment with oral metronidazole.

PATIENT 2

A 64 year old man underwent left upper lobectomy for large cell lung cancer. Intravenous
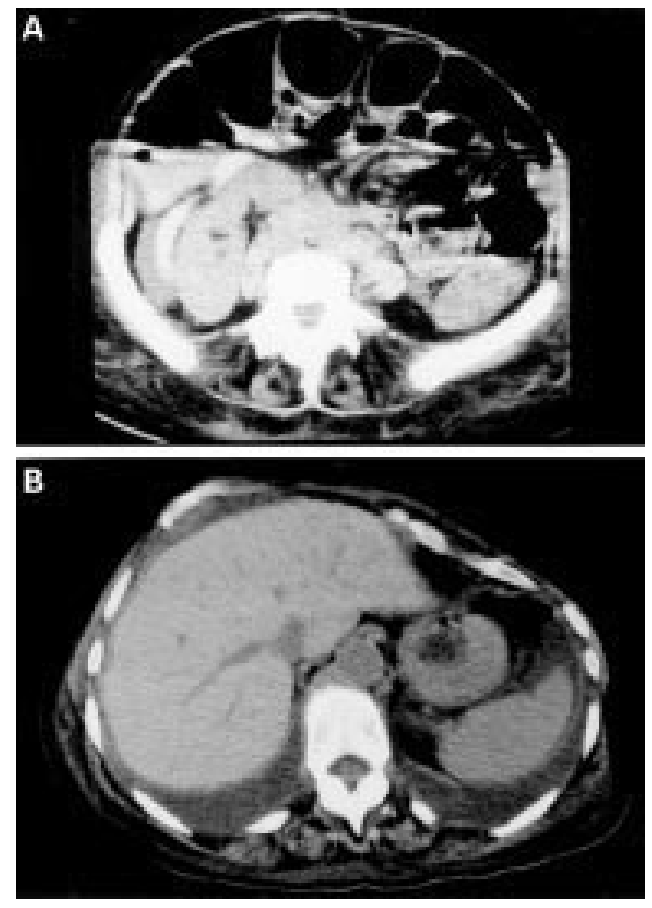

Figure 1: Computed tomogram of the abdomen of patient 1 showing dilated loops of colon $(A)$ and the presence of ascitic fluid (B).

vancomycin and ceftazidime were administered postoperatively for the treatment of pneumonia. Six days after surgery he developed diarrhoea, cramping abdominal pain, a fever of $102^{\circ} \mathrm{F}\left(38.9^{\circ} \mathrm{C}\right)$, diffuse abdominal tenderness, and abdominal distension. A stool test for $C$ difficile cytotoxin was positive and he was treated with oral metronidazole $(500 \mathrm{mg}$, six hourly). An abdominal radiograph showed thickening of the wall of the colon with thumbprinting (fig 2A). Flexible sigmoidoscopy was performed three days later because of increasing abdominal pain and distension, and showed pseudomembranous colitis (fig 2B). Oral vancomycin ( $250 \mathrm{mg}$, six hourly) was initiated. Nine days later he showed no improvement and had continuing diarrhoea, abdominal discomfort, and intermittent fevers. Intravenous immunoglobulin $(200 \mathrm{mg} / \mathrm{kg})$ was administered. Within 24 hours his diarrhoea and fever resolved and did not recur.

C DIFFICILE ANTITOXIN ACTIVITY IN HUMAN IMMUNOGLOBULIN PREPARATIONS

The rapid clinical response of these two patients to intravenous administration of normal pooled human serum immunoglobulin led us to test a variety of human IgG preparations for neutralising antibodies against $C$ difficile toxins $\mathrm{A}$ and $\mathrm{B}$.

All nine of the human immunoglobulin preparations tested contained IgG against $C$ difficile culture filtrate (fig 3A). Antibody levels varied slightly with an approximately fourfold difference in antibody titre between the preparations with the highest and lowest antibody levels. We also measured IgG levels against purified $C$ difficile toxin $\mathrm{A}$ and toxin B. A representative result for an immunoglobulin preparation with mid-range anti- $C$ difficile IgG 


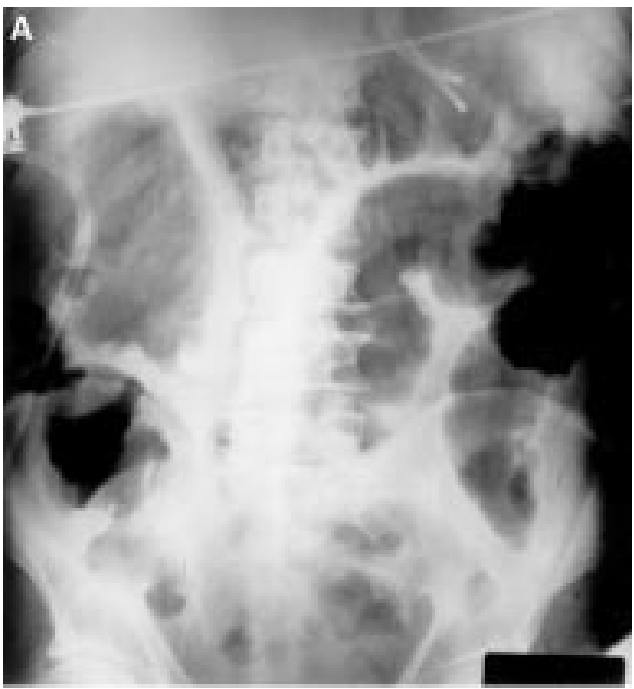

B

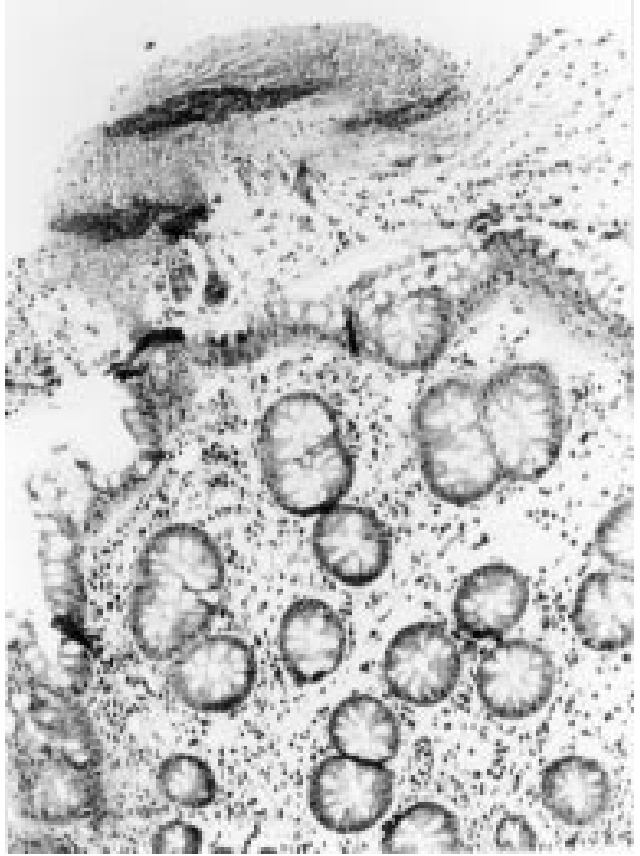

Figure 2: $\quad$ Plain abdominal radiograph of patient 2 showing colonic dilatation and thickening of the colonic wall consistent with notable mucosal oedema $(A)$.

Photomicrograph of sigmoidoscopic biopsy specimen showing acutely inflamed colonic mucosa and an overlying pseudomembrane (B).

levels is presented in fig 3B (this particular preparation is identified by an arrow in fig 3A). All preparations contained $\operatorname{IgG}$ against both $C$ difficile toxin $\mathrm{A}$ and toxin $\mathrm{B}$ as measured by ELISA.

Finally, we determined whether pooled human immunoglobulin was capable of neutralising the cytotoxic effects of $C$ difficile toxins. All nine preparations neutralised $C$ difficile culture filtrate cytotoxicity at IgG concentrations of $0.4-1.6 \mathrm{mg} / \mathrm{ml}$. Control serum from a healthy volunteer who lacked specific antibodies against $C$ difficile toxin $\mathrm{A}$ or toxin $\mathrm{B}$ failed to neutralise the cytotoxicity of $C$ difficile culture filtrate in this assay.
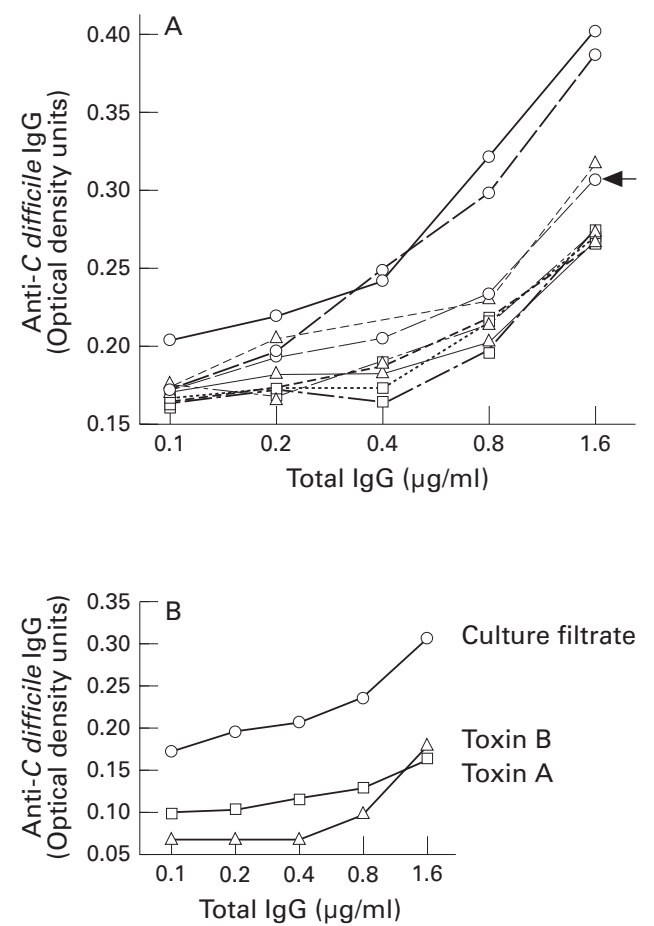

Figure 3: $\quad C$ difficile antitoxin activity in human immunoglobulin preparations. (A) Anti-C difficile culture filtrate IgG levels measured by ELISA in commercially available pooled normal human immunoglobulin preparations. Three lots from each of three suppliers were studied (Alpha Therapeutic Corporation (open triangle), Armour Pharmaceutical Company (open square), and Baxter Healthcare Corporation (open circle). (B) IgG levels against $C$ difficile culture filtrate (open circle), toxin $A$ (open triangle), and toxin $B$ (open square) in a representative immunoglobulin preparation (denoted by the arrow in A).

\section{Discussion}

Most patients who develop $C$ difficile diarrhoea respond promptly to either oral metronidazole or vancomycin. ${ }^{126}$ Diarrhoea may recur when these agents are discontinued but even then almost always resolves quickly when antimicrobial therapy is resumed. Persisting diarrhoea despite appropriate treatment with metronidazole and vancomycin, as occurred in both patients in this report, is unusual. Both patients also had severe colitis as evidenced by pseudomembrane formation, thickening of the colonic wall, abdominal tenderness, and abdominal distension. Severe, unresponsive pseudomembranous colitis may result in colonic perforation, septicaemia, and death. ${ }^{127-30}$ Colectomy may be life saving in these circumstances. However, many patients are considered unfit for colectomy because of advanced age and severe coexisting medical problems. Even those who are considered fit to undergo colectomy for severe pseudomembranous colitis have a mortality rate of approximately $50 \% .^{27-30}$ Thus it was felt that intravenous immunoglobulin treatment for unresponsive pseudomembranous colitis was justified for the two patients presented in this report. In both instances there was rapid clinical improvement immediately following immunoglobulin administration.

Both patients in this report had recognised risk factors for $C$ difficile colitis including anti- 
biotic treatment, admission to hospital, advanced age, malignancy, and recent major surgery. ${ }^{12} 273132$ The elderly and those who experience major surgery or trauma are known to have impaired antibody responses against a range of antigens and this may include reduced $C$ difficile antitoxin production. ${ }^{14} 16{ }^{33}{ }^{34}$ Neither patient had received cytotoxic chemotherapy at the time of onset of diarrhoea but the first patient had a lymphoma which may also be associated with diminished antibody production in response to antigenic challenge.

A number of previous studies have reported low serum antibody levels against $C$ difficile toxins in patients with severe and prolonged $C$ difficile colitis. ${ }^{14}{ }^{18-23}$ Elderly individuals, who are most likely to develop $C$ difficile diarrhoea, may also have lower levels of neutralising antitoxin in their serum. ${ }^{16}$ If inadequate antibody production does indeed contribute to more severe or more prolonged disease, intravenous administration of preformed antitoxin may be beneficial. Passive immunotherapy, either oral or parenteral, is effective in preventing $C$ difficile enterocolitis in animals but little information is available for humans. ${ }^{14} 2435-37$ The largest study to date is our report of intravenous immunoglobulin administration to children with recurrent $C$ difficile diarrhoea. ${ }^{21} 38{ }^{39}$ In that study we demonstrated a notable increase in serum antitoxin A levels following immunoglobulin administration. In this study both patients were treated urgently with immunoglobulin and, unfortunately, serum was not saved to allow measurement of their serum antitoxin antibody levels.

As $C$ difficile colitis is toxin mediated we assume that the immunoglobulin acts by binding and neutralising $C$ difficile toxins. The intravenous administration of $150 \mathrm{mg} / \mathrm{kg}$ of immunoglobulin results in serum IgG levels of greater than $5 \mathrm{mg} / \mathrm{ml}$ whereas toxin neutralising activity is evident in vitro at IgG concentrations of approximately $1 \mathrm{mg} / \mathrm{ml}^{40}$ Thus neutralising levels of IgG against $C$ difficile toxins are readily achieved in the blood following immunoglobulin infusion. However, the precise mechanism of action of intravenous immunoglobulin is still not entirely clear since, to be effective, IgG antitoxin must leave the circulation and bind to toxins $\mathrm{A}$ and $\mathrm{B}$ within the colonic lamina propria or intestinal lumen. ${ }^{91441}$ This may occur as a result of the exudation of serum proteins across an inflamed colonic mucosa.

Our first patient had a recurrence of $C$ difficile diarrhoea four weeks after immunoglobulin infusion. This may simply be the result of discontinuing metronidazole and vancomycin three weeks earlier. However, the timing of her relapse is also consistent with the expected time course of degradation of intravenously administered human IgG. ${ }^{40}$

The animal and human studies discussed earlier indicate that normal pooled human immunoglobulin is a rational therapy for severe $C$ difficile colitis particularly in cases where standard antimicrobial agents prove ineffective. Immunoglobulin treatment carries some risks but these are relatively small in the context of acutely ill patients with severe colitis who are often elderly and debilitated and already receiving multiple medications. A controlled prospective study would be needed to examine properly the efficacy of immunoglobulin in these circumstances. However, the uncommon and urgent nature of this condition makes such a study logistically difficult. The two cases reported here suggest that passive immunotherapy with pooled normal human immunoglobulin may be a useful addition to metronidazole and vancomycin and may hasten recovery or avert colectomy in patients with severe, refractory pseudomembranous colitis.

1 Kelly CP, Pothoulakis C, LaMont JT. Clostridium difficile colitis. N Engl f Med 1994; 330: 257-62

2 McFarland LV, Mulligan ME, Kwok RY, Stamm WE. Nosocomial acquisition of Clostridium difficile infection. N Engl f Med 1989; 320: 204-10.

3 Bongaerts GP, Lyerly DM. Role of toxins A and B in the pathogenesis of Clostridium difficile disease. Microb Pathog 1994; 17: 1-12.

4 Lyerly DM, Krivan HC, Wilkins TD. Clostridium difficile: its disease and toxins. Clin Microbiol Rev 1988; 1: 1-18.

5 Lyerly DM, Lockwood DE, Richardson SH, Wilkins TD. Biological activities of toxins $\mathrm{A}$ and $\mathrm{B}$ of Clostridium difficile. Infect Immun 1982; 35: 1147-50.

6 Riegler M, Sedivy R, Pothoulakis C, Hamilton G, Zacherl J, Bischof $\mathrm{G}$, et al. Clostridium difficile toxin B is more potent than toxin $\mathrm{A}$ in damaging human colonic epithelium in than toxin A in damaging human colo
vitro. f Clin Invest 1995; 95: 2004-11.

7 Triadafilopoulos G, Pothoulakis C, O'Brien MJ, LaMont T. Differential effects of Clostridium difficile toxins A and B on rabbit ileum. Gastroenterology 1987; 93: 273-9.

8 Dove $\mathrm{CH}$, Wang SZ, Price SB, Phelps CJ, Lyerly DM, Wilkins TD, et al. Molecular characterization of the Clostridium difficile toxin A gene. Infect Immun 1990; 58: $480-8$.

9 Kelly CP, Becker S, Linevsky JK, Joshi MA, O'Keane JC, Dickey BF, et al. Neutrophil recruitment in Clostridium difficile toxin A enteritis in the rabbit. $\mathcal{F}$ Clin Invest 1994; 93: $1257-65$.

10 Triadafilopoulos G, Pothoulakis C, Weiss R, Giampaolo C, LaMont JT. Comparative study of Clostridium difficile toxin A and cholera toxin in rabbit ileum. Gastroenterology 1989; 97: 1186-92.

11 von Eichel-Streiber C, Laufenberg-Feldmann R, Sartingen S, Schulze J, Sauerborn M. Cloning of Clostridium difficile toxin $\mathrm{B}$ gene and demonstration of high N-terminal homology between toxin A and B. Med Microbiol Immunol (Berl) 1990; 179: 271-9.

12 Just I, Selzer J, Wilm M, von Eichel-Streiber C, Mann M, Aktories K. Glucosylation of Rho proteins by Clostridium difficile toxin B. Nature 1995; 375: 500-3.

13 Just I, Wilm M, Selzer J, Rex G, von Eichel-Streiber C, Mann M, et al. The enterotoxin from Clostridium difficile (ToxA) monoglucosylates the Rho proteins. $\mathcal{F}$ Biol Chem (ToxA) monoglucosylat

14 Kelly CP. Immune response to Clostridium difficile. Eur $\mathcal{F}$ Gastroenterol Hepatol 1996; 8: 1048-53.

15 Kelly CP, Pothoulakis C, Orellana J, LaMont JT. Human colonic aspirates containing immunoglobulin A antibody to Clostridium difficile toxin A inhibit toxin A-receptor binding. Gastroenterology 1992; 102: 35-40.

16 Nakamura S, Mikawa M, Nakashio S, Takabatake M, Okado I, Yamakawa K, et al. Isolation of Clostridium difficile from the feces and the antibody in sera of young and elderly adults. Microbiol Immunol 1981; 25: 345-51.

17 Viscidi R, Laughon BE, Yolken R, Bo-Linn P, Moench T, Ryder RW, et al. Serum antibody response to toxins A and $\mathrm{B}$ of Clostridium difficile. F Infect Dis 1983; 148: 93-100.

18 Aronsson B, Granstrom M, Mollby R, Nord CE. Serum antibody response to Clostridium difficile toxins in patients antibody response to Clostridium difficile toxins in patients 97-101.

19 Aronsson B, Granstrom M, Mollby R, Nord CE. Enzymelinked immunosorbent assay (ELISA) for antibodies to Clostridium difficile toxins in patients with pseudomembranous colitis and antibiotic-associated diarrhoea. $\mathcal{F}$ Immunol Methods 1983; 60: 341-50.

20 Bacon AE III, Fekety R. Immunoglobulin G directed against toxins $\mathrm{A}$ and $\mathrm{B}$ of Clostridium difficile in the general population and patients with antibiotic-associated diarrhoea. Diagn Microbiol Infect Dis 1994; 18: 205-9.

21 Leung DY, Kelly CP, Boguniewicz M, Pothoulakis C, LaMont JT, Flores A. Treatment with intravenously administered gammaglobulin of chronic relapsing colitis induced
by Clostridium difficile toxin. F Pediatr 1991; 118: 633-7.

22 Mulligan ME, Miller SD, McFarland LV, Fung HC, Kwok RY. Elevated levels of serum immunoglobulins in asymptoRY. Elevated levels of serum immunoglobulins in asympto-
matic carriers of Clostridium difficile. Clin Infect Dis 1993; 16 (suppl 4): S239-44 
23 Warny M, Vaerman JP, Avesani V, Delmee M. Human antibody response to Clostridium difficile toxin $\mathrm{A}$ in relation to .

24 Kelly CP, Pothoulakis C, Vavva F, Castagliuolo I, Bostwick EF, O'Keane JC, et al. Anti-Clostridium difficile bovine immunoglobulin concentrate inhibits cytotoxicity and enterotoxicity of C. difficile toxins. Antimicrob Agents Chemother 1996; 40: 373-9.

25 Pothoulakis C, Barone LM, Ely R, Faris B, Clark ME, Franzblau C, et al. Purification and properties of Clostridium difficile cytotoxin B. F Biol Chem 1986; 261: 1316-21.

26 Kelly CP, LaMont JT. Treatment of Clostridium difficile diarrhoea and colitis. In: Wolfe MM, ed. Gastrointestinal pharmacotherapy. Philadelphia: WB Saunders, 1993; 199212 .

27 Medich DS, Lee KK, Simmons RL, Grubbs PE, Yang HC, Showalter DP. Laparotomy for fulminant pseudomembranous colitis. Arch Surg 1992; 127: 847-52.

28 Morris LL, Villalba MR, Glover JL. Management of pseudomembranous colitis. Am Surg 1994; 60: 548-51.

29 Rubin MS, Bodenstein LE, Kent KC. Severe Clostridium Rubin MS, Bodenstein LE, Kent KC. Severe Clo
difficile colitis. Dis Colon Rectum 1995; 38: 350-4.

30 Trudel JL, Deschenes M, Mayrand S, Barkun AN. Toxic Trudel JL, Deschenes M, Mayrand S, Barkun AN. Toxic
megacolon complicating pseudomembranous enterocolitis. Dis Colon Rectum 1995; 38: 1033-8

31 Bender BS, Bennett R, Laughon BE, Greenough WB III, Gaydos C, Sears SD, et al. Is Clostridium difficile endemic in chronic-care facilities? Lancet 1986; ii: 11-3.

$32 \mathrm{McF}$ arland LV. Epidemiology of infectious and iatrogenic nosocomial diarrhoea in a cohort of general medicine patients. Am F Infect Control 1995; 23: 295-305.

33 Schwab R, Walters CA, Weksler ME. Host defense mechanisms and aging. Semin Oncol 1989; 16: 20-7.
34 Weksler ME. Immune senescence. Ann Neurol 1994; 35 (suppl): S35-7.

35 Corthier G, Muller MC, Wilkins TD, Lyerly D, L'Haridon R. Protection against experimental pseudomembranous colitis in gnotobiotic mice by use of monoclonal antibodies against Clostridium difficile toxin A. Infect Immun 1991; 59: 1192-5.

$36 \mathrm{Kim}$ PH, Iaconis JP, Rolfe RD. Immunization of adult hamsters against Clostridium difficile-associated ileocecitis and transfer of protection to infant hamsters. Infect Immun 1987; 55: 2984-92.

37 Lyerly DM, Bostwick EF, Binion SB, Wilkins TD. Passive immunization of hamsters against disease caused by Clostridium difficile by use of bovine immunoglobulin $\mathrm{G}$ concentrate. Infect Immun 1991; 59: 2215-8.

38 Tjellstrom B, Stenhammar L, Eriksson S, Magnusson KE. Oral immunoglobulin A supplement in treatment of Clostridium difficile enteritis [letter]. Lancet 1993; 341: Clostridiu.

39 Hassett J, Meyers S, McFarland L, Mulligan ME. Recurrent Clostridium difficile infection in a patient with selective gG1 deficiency treated with intravenous immune globulin and Saccharomyces boulardii. Clin Infect Dis 1995; 20 (suppl 2): S266-8.

40 Pirofsky B, Campbell SM, Montanaro A. Individual patient variations in the kinetics of intravenous immune globulin administration. F Clin Immunol 1982; 2: 7S-14S.

41 Pothoulakis C, LaMont JT, Eglow R, Gao N, Rubins JB, Theoharides TC, et al. Characterization of rabbit ileal receptors for Clostridium difficile toxin A. Evidence for a receptor-coupled G protein. F Clin Invest 1991; 88: 119-25. 